\title{
Comparison of Classical and Secondary Cytologic Criteria Relative to Hybrid Capture for Diagnosing Cervical-vaginal Infection by Human Papillomavirus
}

\section{Comparação entre os critérios citológicos clássicos e secundários para o diagnóstico de infecção cérvico-vaginal por papiloma vírus humano em relação à captura híbrida}

\author{
Renata Margarida Etchebehere ${ }^{1}$ Élia Cláudia Souza Almeida ${ }^{2}$ Eliângela Castro Côbo ${ }^{3}$ \\ Ana Cristina da Rocha Duque ${ }^{4}$ Eddie Fernando Cândido Murta ${ }^{2}$ Sheila Jorge Adad $^{2}$
}

1 Surgical Pathology Service, Clinical Hospital, Hospital de Clínicas da Universidade Federal do Triângulo Mineiro (UFTM), Uberaba, Minas Gerais, Brazil

2 Post Graduate Program in Health Sciences, UFTM, Uberaba, Minas Gerais, Brazil

Address for correspondence Renata Margarida Etchebehere, PhD, Universidade Federal do Triângulo Mineiro - UFTM, Rua Getúlio Guaritá, 130-Abadia, 38025-440 - Uberaba, MG, Brazil (e-mail: renataetch@hotmail.com).

${ }^{3}$ Special Pathology Discipline, Universidade Federal do Triângulo Mineiro (UFTM), Uberaba, Minas Gerais, Brazil

${ }^{4}$ Maternal and Infant Department, Discipline of Gynecology and Obstetrics, UFTM, Uberaba, Minas Gerais, Brazil

Rev Bras Ginec Obst 2016;38:41-46.

\begin{abstract}
Keywords

- HPV

- cervical neoplasia

- vaginal smears

- papillomavirus

- DNA

Objective To compare the diagnostic accuracy of the classic Meisels cytologic criteria and the Schneider secondary criteria relative to the hybrid capture method for diagnosing HPV infection.

Methods This was a retrospective study performed at a public university hospital. A total of 41 patients with a cytologic diagnosis of HPV infection and $40 \mathrm{HPV}$-negative patients were selected for review of the cervical-vaginal smears seeking to classical and secondary criteria. A single pathologist reviewed the slides in search of the criteria. The classical and secondary cytologic criteria were compared with the hybrid capture for diagnosing HPV infection. Bartleti test was applied for the age analysis, and Fisher's exact test was used to compare proportions. The tests were considered significant when the probability of rejecting the null hypothesis was less than $5 \%(p<0.05)$.

Results The Meisels criteria were less sensitive (34.0\%) than the secondary Schneider criteria $(57.5 \%)$ when compared with the hybrid capture $(p<0.0001)$, although the specificity of the former criteria was non-significantly higher $(91.2 \%$ and $67.7 \%$, respectively). In cases of moderate or intense inflammation, the sensitivity and specificity of the Schneider criteria were decreased, $33.3 \%$ and $50.0 \%$ respectively $(p=0.0115)$.
\end{abstract}

received

September 18, 2015

accepted

October 28, 2015
DOI http://dx.doi.org/ 10.1055/s-0035-1570105. ISSN 0100-7203.
Copyright $\odot 2016$ by Thieme Publicações License terms Ltda, Rio de Janeiro, Brazil

c) $(\oplus) \$$ 


\section{Resumo}

Palavras-chave
- HPV
- neoplasia do colo do
útero
- esfregaço vaginal
- papilomavírus
- DNA

Conclusions Compared with hybrid capture for diagnosis of HPV infection, the sensitivity of the secondary Schneider criteria was higher than the classical Meisels criteria. Moderate or intense inflammation reduces the sensitivity and specificity of the secondary Schneider criteria for diagnosing HPV infection using the hybrid capture as the gold standard.

Objetivo Comparar a acurácia diagnóstica dos critérios citológicos clássicos de Meisels com a dos critérios secundários de Schneider em relação a captura híbrida para o diagnóstico de infecção pelo HPV.

Métodos Trata-se de estudo retrospectivo realizado em hospital público universitário. Quarenta e uma pacientes com diagnóstico citológico de infecção pelo HPV e 40 pacientes HPV-negativas foram selecionadas para avaliação dos esfregaços cervicaisvaginais em busca dos critérios clássicos e secundários. Um único patologista reviu as lâminas. Os critérios citológicos clássicos e secundários foram comparados com a captura híbrida para o diagnóstico de infecção pelo HPV. O teste de Bartleti foi aplicado para a análise das idades e o teste exato de Fisher para comparar proporções. Os testes foram considerados significativos quando a probabilidade de rejeitar a hipótese de nulidade foi menor que $5 \%(p<0,05)$.

Resultados Os critérios de Meisels foram menos sensíveis (34,0\%) que os secundários de Schneider $(57,5 \%)$ quando comparados com a captura híbrida $(p<0,0001)$, embora a especificidade dos critérios de Meisels não tenha sido significativamente superior (91,2\% e $67,7 \%$, respectivamente). Em casos de inflamação moderada ou intensa, a sensibilidade e especificidade dos critérios secundários de Schneider foram diminuídas, $33,3 \%$ e $50,0 \%$, respectivamente $(p=0,0115)$.

Conclusões Comparado a captura híbrida para o diagnóstico da infecção pelo HPV, a sensibilidade dos critérios secundários de Schneider foi maior que a dos critérios clássicos de Meisels. Inflamação moderada ou intensa reduziu a sensibilidade e especificidade dos critérios secundários de Schneider para o diagnóstico de infecção pelo HPV utilizando a captura híbrida como padrão-ouro.

\section{Introduction}

Cervical cancer is the third most common cancer among women. In developed countries, the diagnosis is made earlier; consequently, the 5-year survival rate is higher. In the last few decades, the incidence of cervical cancer has decreased in countries with effective screening systems, probably as result of the early treatment of precancerous lesions. Thus, it is important to understand the minimal abnormalities in cervical-vaginal cytology. ${ }^{1-3}$

With the development of molecular biological techniques, epidemiological and laboratory findings have identified $h u$ man papillomavirus (HPV) as the principal agent involved in the geneses of cervical cancer and cervical intraepithelial neoplasia. This evidence has increased the importance of the morphological identification of HPV infection in cervicalvaginal cytology. ${ }^{1,4-8}$ Classically, the natural history of cervical cancer starts with infection by HPV. Subsequent progressive intraepithelial transformations can evolve into invasive neoplasia in the long term. This connection has raised interest in establishing and perfecting the diagnosis of this infection, as well as identifying risk factors for it, to detect populations susceptible to HPV-induced cervical carcinogenesis. ${ }^{4}$

Although cellular biological tests are more sensitive in diagnosing HPV infection than cytological tests, access become larger and the cost somewhat lower, some factors limit their routine use, including cost and methodological difficulty, particularly in poorer countries. ${ }^{9,10}$ Thus, the cytologic Papanicolaou exam (also known as the Pap smear) remains the main screening method for cervical cancer. ${ }^{3,11}$ Where as Papanicolaou first described the exfoliated squamous cells of vaginal and cervical condyloma acuminatum, ${ }^{12}$ it was Meisels and Fortin ${ }^{13}$ and Meisels, Fortin and Roy ${ }^{14}$ who identified the cell changes that, currently, are considered pathognomonic for HPV infection (i.e., classic koilocytosis and dyskeratosis). These criteria for HPV infection are very specific, but not very sensitive. ${ }^{3,11}$ To increase the sensitivity of the test without substantially reducing specificity, various authors have sought other "secondary" cytologic indices. ${ }^{3,15-19}$

Among the secondary criteria proposed, the most accepted are those of Schneider et al. (1987), ${ }^{15}$ which include: 
slight koilocytosis or an outline of koilocytosis, slight dyskeratosis, cleared cytoplasm, keratin hyaline granules, condensation of filaments in the cytoplasm, fusiform cells, hyperchromatic nuclei, bi- or multinucleation, and perinuclear halo.

Nevertheless, there is still some controversy about the use of secondary criteria. ${ }^{16-19}$ Thus, we wanted to compare the use of classical and secondary cytologic criteria to the hybrid capture (HC) molecular biological test for diagnosing HPV infection. The HC method was chosen because it is easily performed, yields rapid results, has good sensitivity for latent, subclinical, and clinical infections, and can detect HPV infection anywhere in the woman's lower genital tract. $^{5,9,20}$

The objective of this study was to compare the classic cytologic Meisels criteria $(\mathrm{CMC})^{13,14}$ and the secondary criteria proposed by Schneider et al. ${ }^{15}$ (SSC) to the molecular biological HC method for diagnosing HPV infection.

\section{Methods}

The Research Ethics Committee at the Universidade Federal Triângulo Mineiro approved this research (protocol no. 0281 on 12.20.2002). We performed a pilot study to determine the sample size. The sample calculation was performed for two proportions, following Arango. ${ }^{21}$ Applying the formula to compare two samples, we calculated $n=27$. Using the value 1.96 with an $\alpha$ level of 0.05 and $\beta$ level of 0.084 , we determined that the sample size for this study was sufficient to find significant differences when they actually exist.

This retrospective study included 41 patients with a cytologic diagnosis of HPV infection by Pap smear. Patients received care between June 2000 and October 2002 at the Gynecology and Obstetrics outpatient clinic of a public university hospital. All patients signed an informed consent form to demonstrate that they agreed to participate in the study. These cases were paired with 40 control cases with a normal routine or inflammatory cervical-vaginal cytology, collected during the same sample period. When the 81 patients returned to the clinic, we collected material to perform the HC test to diagnose HPV infection.

The same observer reviewed the slides according to the $\mathrm{CMC}^{13,14}$ and SSC. ${ }^{15}$ The observer was unaware of the previous results of the Papanicolaou and HC exams. We considered the cytology as positive for a diagnosis of HPV infection based on the CMC when classic koilocytosis or dyskeratosis was present. The cytology was considered positive according to the SSC when a minimum of five of the nine criteria were present.

We also analyzed the presence of inflammation and infection by other agents. To diagnose inflammation, we analyzed the presence of neutrophils and cell changes, such as an increase in nuclear volume, binucleation, hyperchromasia, margination of chromatin, small perinuclear halo, and cytoplasmic vacuolization. ${ }^{3}$ We classified the inflammatory process as slight, moderate or intense, based on the intensity of the inflammatory exudate and the frequency of inflammation-related cell changes. Diagnosis of infection was based only on the morphological identification of the agent. $^{22}$

The obtained results were entered into a database for statistical analysis via Microsoft Access 2000®. GRAPHPAD INSTAT ${ }^{\circledR}$ (version 3.0) was used to perform the statistical calculations. Bartleti test was applied for the age analysis, and Fisher's exact test was used to compare proportions. The tests were considered significant when the probability of rejecting the null hypothesis was less than $5 \%(p<0.05)$.

\section{Results}

In the HC exam, 47 (58\%) of the 81 cases tested positive for HPV infection. The age of patients with positivity for HPVDNA by HC ranged from 14 to 47 years, with an average of $24.1 \pm 6.5$ years. In the HPV-DNA-negative group, the age ranged from 14 to 50 years, with an average age of $25.18 \pm 6.56$ ( $p=0.4693$ between groups).

Using the $\mathrm{CMC}$ and considering the $\mathrm{CH}$ as gold standard for diagnosing HPV infection, of the 81 cases, $19.8 \%$ were true positives and $38.3 \%$ true negatives. The specificity was $91.2 \%$ and the sensitivity by $34 \%$ (-Table 1 ).

Using the SSC, $33.3 \%$ of the 81 cases were classified as true positives and $23(28.39 \%)$ as true negatives. The sensitivity was $57.5 \%$, and the specificity $67.7 \%$ (-Table 2 ).

All cases that were positive by $\mathrm{HC}$ and $\mathrm{CMC}$ were also positive by SSC (- Table 3). Thus, use of the SSC increased the sensitivity for diagnosing HPV infection from $34 \%$ to $57.5 \%$ $(p<0.0001)$. The difference in specificity between the SSC and $\mathrm{CMC}$ was not statistically significant.

The most frequently encountered SCC were: bi-or multinucleation (68 cases), nuclear hyperchromasia (61 cases), perinuclear halo (58 cases), slight koilocytosis (54 cases), and dyskeratosis (36 cases). These criteria were also common in

Table 1 Cytologic analysis of 81 cases based on the classic Meisels criteria (CMC), using hybrid capture (HC) as the gold standard for diagnosing HPV infection in patients accompanied on ambulatory of Universidade Federal do Triângulo Mineiro

\begin{tabular}{|l|l|l|l|}
\hline & $\begin{array}{l}\text { Positive HC } \\
\mathbf{n}(\%)\end{array}$ & $\begin{array}{l}\text { Negative HC } \\
\mathbf{n}(\%)\end{array}$ & $\begin{array}{l}\text { Total } \\
\mathbf{n}(\%)\end{array}$ \\
\hline Positive CMC & $16(34.1)$ & $3(8.8)$ & $19(23.4)^{*}$ \\
\hline Negative CMC & $31(65.9)$ & $31(91.2)$ & $62(76.6)$ \\
\hline Total & $47(100.0)$ & $34(100.0)$ & $81(100.0)$ \\
\hline
\end{tabular}

Fisher's exact test; ${ }^{*} p=0.0087$. 
Table 2 Cytologic analysis of 81 cases based on Schneider's secondary criteria (SSC), relative to hybrid capture (HC) as the gold standard for diagnosing HPV infection in patients accompanied on ambulatory of Universidade Federal do Triângulo Mineiro

\begin{tabular}{|l|l|l|l|}
\hline & $\begin{array}{l}\text { Positive HC } \\
\mathbf{n}(\%)\end{array}$ & $\begin{array}{l}\text { Negative HC } \\
\mathbf{n}(\%)\end{array}$ & $\begin{array}{l}\text { Total } \\
\mathbf{n}(\%)\end{array}$ \\
\hline Positive SSC & $27(57.4)$ & $11(32.4)$ & $38(46.9)^{*}$ \\
\hline Negative SSC & $20(42.6)$ & $23(67.6)$ & $43(53.1)$ \\
\hline Total & $47(100.0)$ & $34(100.0)$ & $81(100.0)$ \\
\hline
\end{tabular}

Fisher's exact test; ${ }^{*} p=0.0417$.

Table 3 Distribution of the 47 HPV-DNA-positive cases, according to cytologic analysis by Schneider's secondary criteria (SSC) and the classic Meisels criteria (CMC) in patients accompanied on ambulatory of Universidade Federal do Triângulo Mineiro

\begin{tabular}{|l|l|l|l|}
\hline & $\begin{array}{l}\text { Positive SSC } \\
\mathbf{n}(\%)\end{array}$ & $\begin{array}{l}\text { Negative SSC } \\
\mathbf{n}(\%)\end{array}$ & $\begin{array}{l}\text { Total } \\
\mathbf{n}(\%)\end{array}$ \\
\hline Positive CMC & $16(59.2)$ & 0 & $16(34.0)^{*}$ \\
\hline Negative CMC & $11(40.8)$ & $20(100.0)$ & $31(66.0)$ \\
\hline Total & $27(100.0)$ & $20(100.0)$ & $47(100.0)$ \\
\hline
\end{tabular}

Fisher's exact test; ${ }^{*} p<0.0001$.

cases with a negative $\mathrm{HC}$ result, without any significant difference. Cleared cytoplasm was the only criteria that, in isolation, showed a significant difference for the groups with positive and negative HC results; however, it was present in only $30.86 \%$ of positive cases and was a common finding (11.12\%) in negative cases.

Some of the SSC were also often found in cases of inflammation or infection, especially in more accentuated cases, which may have been related to the increased number of false positives. In reviewing the slides, 76 of the 81 cases (93.8\%) showed varying degrees of inflammation, including $81.5 \%$ of slight, $14.5 \%$ of moderate, and $4 \%$ of intense inflammation. Among patients with inflammatory changes, most had nonspecific inflammation (lactobacilli), $15.8 \%$ had a diagnosis of infection by Gardnerella vaginalis, $14.5 \%$ had a diagnosis of infection by Candida sp, and $6.6 \%$ had predominance of cocobacilli.

We separated the cytologies into two groups: cases with slight or no inflammation, and cases with moderate or intense inflammation. Of the 67 cases with slight or no inflammation, $47.8 \%$ had five or more SSC (i.e., were considered positive for HPV infection by SSC). Of these cases, $21.9 \%$ had a negative HC result, and $78.1 \%$ had a positive $\mathrm{HC}$ result. The sensitivity of the SSC relative to $\mathrm{HC}$ was $60.98 \%$, and the specificity was $73.08 \%$. There was a statistically significant difference $(p=0.0115)$ between the groups, indicating that the SSC were good indicators of infection by HPV in cases with slight or no inflammation.

Among the 14 cases with moderate or intense inflammation, $42.9 \%$ were considered positive for HPV infection, according to the SSC. Of these 6 cases, 33.3\% had a positive $\mathrm{HC}$ result, and $66.7 \%$ had a negative $\mathrm{HC}$ result. The sensitivity of the SSC in relation to $\mathrm{HC}$ was $33.3 \%$, and the specificity $50 \%$. The sensitivity and specificity of the SSC in more intense inflammatory situations was lower.

\section{Discussion}

The Pap test has worked as well as it has despite the poor sensitivity of a single test because it is repeated periodically during the span of a woman's lifetime. ${ }^{23}$

Despite the high specificity, the sensitivity of the CMC is low. Compared with HC for diagnosis of HPV infection, the sensitivity of the SSC was higher than CMC, but the specificity was lower, agreement with other authors. ${ }^{15-18}$ Thus, the secondary criteria described by Schneider et al. ${ }^{15}$ appear to have a better ability to detect HPV infection in true-positive patients.

Other authors found sensitivity for non-classic criteria of only $15.8 \%$ and the specificity of $100 \%$ in samples previously diagnosed by polymerase chain reaction (PCR). However, they used different cytologic criteria from our study, examining only nuclear hyperchromasia, pleomorphism, and the nucleus/cytoplasm relationship in HIV infected patients. ${ }^{24}$ In other study, after including secondary criteria, they observed that the diagnostic frequency for HPV using cytology increased from $24.4 \%$ to $75.6 \%{ }^{18}$ Again, these authors used different secondary cytologic criteria from those used in our study. In comparing cytology with molecular hybridization, the first study obtained an agreement of $48 \%$ when they used only koilocytosis as a cytologic criterion. However, when they also included dyskeratosis, dyskariosis, binucleation, and multinucleation agreement increased to $75 \%{ }^{24}$ Different research indicated that the inclusion of non-classical cytomorphologic signs increased the sensitivity of the cytologic test for detecting HPV when compared with PCR, although they used monobed, rather than conventional, cytology. ${ }^{17}$ Using PCR for HPV 16, an study concluded that the classic cell changes were not the only ones that permitted a diagnosis of HPV infection. ${ }^{11}$ 
We found a reduction in the specificity and sensitivity of the SSC in cases with moderate or intense inflammation. This finding probably stems from the superimposition of cytologic changes related to inflammation with certain secondary criteria involved in the HPV diagnosis. Moreover, the inflammatory exudate may have made it difficult to visualize the cytologic criteria. ${ }^{3}$ Thus, we believe that it is better not to use the SSC in cases with moderate or intense inflammation, to avoid an increase in the number of false positives.

Studing the importance of the application of the nonclassical criteria compared with HC, they found inflammation in $61.5 \%$ of cases, although they did not classify the intensity of inflammation. ${ }^{19}$ Other research identified inflammation in only $4.9 \%$ of cases when comparing nonclassical criteria with PCR. ${ }^{18}$ Nevertheless, their findings conflict with those in the literature, as inflammation is a very common finding in cervical-vaginal cytology, particularly unspecific cervicitis in young patients., ${ }^{3,22}$ In addition, the authors did not classify the intensity of the inflammation.

Despite the introduction of the HPV vaccines, screening programs using cervical-vaginal cytology must continue. The vaccine does not completely protect against cervical cancer and is still not universally used. ${ }^{25-27}$

Compared with HC for diagnosis of HPV infection, the sensitivity of the SSC was higher than CMC. Moderate or intense inflammation reduces the sensitivity and specificity of the SSC for diagnosing HPV infection using the HC as the gold standard. We believe that, with greater use of the vaccine against HPV, there will be an increase in the number of cytologies with minimal cell changes, making it even more important to recognize the non-classical changes that are associated with HPV infection.

\section{Conflicts of Interest}

None.

\section{Acknowledgments}

To National Council for Scientific and Technological Development (Conselho Nacional de Desenvolvimento Científico e Tecnológico - CNPq) for financial assistance (Application $n^{\circ}$ 477539/2001-7/Research Productivity Grant: Application $n^{\circ} 520629 / 99-0$ NV); FIOCRUZ of Rio de Janeiro, RJ, for donation of the Hybrid Capture machine; and Doctor Uilho Antônio Gomes of the Ribeirão Preto São Paulo University (FMRP - USP), for reviewing the statistical analysis.

\section{References}

1 Guarisi R, Hardy E, Derchain SFM, Fonsechi-Carvasan GA, Borges JBR. Rastreamento, diagnóstico e tratamento das lesões precursoras e do câncer invasor do colo uterino no município de Franco da Rocha, SP. Rev Bras Cancerol 2004;50(1):7-15

2 Brasil. Ministério da Saúde. Instituto Nacional de Câncer José Alencar Gomes da Silva [Internet]. Tipos de câncer: colo do útero. Brasília (DF): Ministério da Saúde; 2014 [citado 2015 Jul 10]. Disponível em: $<$ http:/ www.inca.gov.br/wps/wcm/connect/tiposdecancer/site/home/ colo_utero>
3 DeMay RM. The art and science of cytopathology. 2nd ed. Vol. 1, Exfoliative cytology. Chicago: American Society of Clinical Pathologists Press; 2012. Chapter 1, The pap test; p. 2-149

4 Silva C, Almeida EC, Côbo EdeC, Zeferino VF, Murta EF, Etchebehere RM. A retrospective study on cervical intraepithelial lesions of low-grade and undetermined significance: evolution, associated factors and cytohistological correlation. Sao Paulo Med J 2014;132(2):92-96

5 Cope JU, Hildesheim A, Schiffman MH, et al. Comparison of the hybrid capture tube test and PCR for detection of human papillomavirus DNA in cervical specimens. J Clin Microbiol 1997;35(9): 2262-2265

6 Curry CL, Sage YH, Vragovic O, Stier EA. Minimally abnormal Pap testing and cervical histology in HIV-infected women. J Womens Health (Larchmt) 2012;21(1):87-91

7 Cuzick J, Arbyn M, Sankaranarayanan R, et al. Overview of human papillomavirus-based and other novel options for cervical cancer screening in developed and developing countries. Vaccine 2008; 26(Suppl 10):K29-K41

8 Muñoz N. Human papillomavirus and cancer: the epidemiological evidence. J Clin Virol 2000;19(1-2):1-5

9 Nomelini RS, Guimarães PD, Candido PA, Campos AC, Michelin MA, Murta EFC. Prevention of cervical cancer in women with ASCUS in the Brazilian Unified National Health System: costeffectiveness of the molecular biology method for HPV detection. Cad Saude Publica 2012;28(11):2043-2052

10 Akbar S, Pervez SN, Shah W. Manual liquid based cytology for Pap smear preparation and HPV detection by PCR in Pakistan. Asian Pac J Cancer Prev 2015;16(2):579-583

11 Kashyap V, Hedau S, Bhambhani S. Defining the validity of classical and non-classical cellular changes indicative of lowgrade squamous intraepithelial lesion encompassing human papillomavirus infection in relation to human papillomavirus deoxyribonucleic acid testing. J Cytol 2011;28(4):159-164

12 Papanicolaou GN. Atlas of exfoliative cytology. Cambridge: Harvard University Press; 1954

13 Meisels A, Fortin R. Condylomatous lesions of the cervix and vagina. I. Cytologic patterns. Acta Cytol 1976;20(6):505-509

14 Meisels A, Fortin R, Roy M. Condylomatous lesions of the cervix. II. Cytologic, colposcopic and histopathologic study. Acta Cytol 1977;21(3):379-390

15 Schneider A, Meinhardt G, De-Villiers EM, Gissmann L. Sensitivity of the cytologic diagnosis of cervical condyloma in comparison with HPV-DNA hybridization studies. Diagn Cytopathol 1987; 3(3):250-255

16 Roteli-Martins CM, Alves VA, Santos RT, Martinez EZ, Syrjänen KJ, Derchain SF. Value of morphological criteria in diagnosing cervical HPV lesions confirmed by in situ hybridization and hybrid capture assay. Pathol Res Pract 2001;197(10): 677-682

17 Bollmann M, Bánkfalvi A, Trosic A, Speich N, Schmittt C, Bollmann R. Can we detect cervical human papillomavirus (HPV) infection by cytomorphology alone? Diagnostic value of non-classic cytological signs of HPV effect in minimally abnormal Pap tests. Cytopathology 2005;16(1):13-21

18 Kaneshima EN, Suzuki LE, Irie MMT, Yoshida CS, Silva SFM, Consolaro MEL. Importância da aplicação de critérios morfológicos não clássicos para o diagnóstico citopatológico de Papilomavírus humano (HPV) previamente detectado por PCR. Acta Bioquím Clin Latinoam. 2005;39(1):61-68

19 Jordão AV, Ruggeri LS, Chiucheta GIR, Piva S, Consolaro MEL. Importância da aplicação de critérios morfológicos não clássicos para o diagnóstico citomorfológico de papilomavírus humano. J Bras Patol Med Lab. 2003;39(1):81-89

20 Rebolj M, Lynge E, Ejegod D, Preisler S, Rygaard C, Bonde J. Comparison of three human papillomavirus DNA assays and one mRNA assay in women with abnormal cytology. Gynecol Oncol 2014;135(3):474-480 
21 Arango HG. Bioestatística: teórica e computacional. 3a ed. Rio de Janeiro: Guanabara-Koogan; 2009

22 Adad SJ, de Lima RV, Sawan ZT, et al. Frequency of Trichomonas vaginalis, Candida sp and Gardnerella vaginalis in cervical-vaginal smears in four different decades. Sao Paulo Med J 2001;119(6): 200-205

23 Thaxton L, Waxman AG. Cervical cancer prevention: immunization and screening 2015. Med Clin North Am 2015;99(3):469-477

24 de Faria IM, Melo VH, de Castro LP, et al. [Accuracy of oncotic cytology for HPV infection diagnosis on the cervix uteri of HIV- infected women]. Rev Bras Ginecol Obstet 2008;30(9):437-444 Portuguese

25 Wentzensen N, Klug SJ. Cervical cancer control in the era of HPV vaccination and novel biomarkers. Pathobiology 2009;76(2):82-89

26 Sopracordevole F, Cigolot F, Mancioli F, Agarossi A, Boselli F, Ciavattini A. Knowledge of HPV infection and vaccination among vaccinated and unvaccinated teenaged girls. Int J Gynaecol Obstet 2013;122(1):48-51

27 Nigam A, Saxena P, Acharya AS, Mishra A, Batra S. HPV vaccination in India: critical appraisal. ISRN Obstet Gynecol 2014;2014:394595 